\title{
Impacto dos Ramnolipídeos na disruptura de biofilmes em peças de aço inox e titânio de uso ortopédico
}

\author{
Adriano G. Parreira*; Danielle de Almeida; Cibele G. Bastos; Mauro Ezio \\ E. Pires; Silva, J.A.; Gonçalves, D.B.; Paulo A. Granjeiro \\ Laboratório de Processos Biotecnológicos e Purificação de Macromoléculas, Campus Centro Oeste, Universidade Federal \\ de São João Del-Rei, Divinópolis/MG \\ *e-mail: aguiparreira@ufsj.edu.br
}

\section{Resumo}

Ramnolipídeos são surfactantes de origem bacteriana que apresentam atividade antitumoral, antimicrobiana, anti-adesiva, além de baixa toxicidade e alta estabilidade. Há poucos relatos na literatura que evidenciam o efeito antiadesivo de biossurfactantes produzidos por Pseudomonas aeruginosa quando aplicados em peças metálicas de uso ortopédico. A potencialidade dos ramnolipídeos como inibidores da adesão dos isolados formadores de biofilme Escherichia coli ATCC 25922, Staphylococcus aureus ATCC 29213 e Staphylococcus epidermidis ATCC 12228 em superfícies de materiais em aço inoxidável e ligas detitânio (Ti-6Al-4V) de uso ortopédico foi avaliada neste trabalho. Após o cultivo de isolados de P. aeruginosa ATCC 25619 em diferentes meios minerais foram realizadas as etapas de centrifugação, teste do colapso da gota, tensiometria e precipitação ácida para a seleção do melhor meio de cultura e obtenção de extratos de biossurfactantes pré-purificados. As tensões superficiais na presença do biosurfactante foram reduzidas em relação ao controle e apresentaram valores $(\mathrm{mN} / \mathrm{m})$ de $31,93(0,24), 33,03(0,36)$ e 29,64 $(0,26)$ para os meios M2 modificado, M3 e meio East (ME), respectivamente. O biossurfactante foi pré-condicionado em diferentes concentrações sobre os materiais de uso ortopédico. O maior efeito anti-adesivo foi na concentração de $10 \mathrm{mg} / \mathrm{mL}$, o qual apresentou redução de até $75 \%$ na adesão de $S$. aureus em peças de titânio e $65 \%$ para $S$. epidermidis em peças de aço inox após seu précondicionamento com o biossurfactante parcialmente purificado. O ramnolipídio estudado apresenta potencial aplicação biotecnológica no desenvolvimento de biomateriais nas áreas de saúde humana e animal. 
Palavras-chave: adesão bacteriana, aço inoxidável, titânio, ramnolipídeos, Staphylococcus aureus. 